\title{
Kajian Literatur Efektifitas Pemasaran Produk dengan Menggunakan Sistim Online Marketing di Era Disruption
}

\author{
Teguh Suripto \\ Fakultas Agama Islam Universitas Alma Ata \\ Jl. Brawijaya No.99, Jadan, Tamantirto, Kasihan, Bantul, Daerah Istimewa Yogyakarta 55184 \\ email: teguh_suripto@yahoo.com
}

\begin{abstract}
The era of disruption is an era that will change not only the way the business will go but the business fundamentals, starting from the cost structure to the culture, even to the idiology of the industry (Renald Kasali, 2017). In the era of disruption of business change is very visible, the way of doing business that once strongly emphasized owning became ownership (sharing roles, collaboration resources). One of the units in a company that is greatly affected in discruption is the field of marketing. The marketing sector is the spearhead of the company that is most quickly affected. One form of discruption influence in marketing is the presence of an online marketing system. The marketing system is called online, because it uses internet networks as a means of marketing goods or services to consumers. Some important problems that are often faced in online product marketing are the need to clearly understand the marketing concept, then also an understanding of the media that can be used, as well as a good marketing strategy. The study was conducted using qualitative descriptive methods, namely using literature or literature, using journals, books, magazines, and the web that are relevant to research. The conclusion in this study is that Era of Discruption is an era that will change not only the way business is done but up to its business fundamentals, an important problem that is often faced in online product marketing is the need to clearly understand marketing concepts, then understanding media can be used, as well as a good marketing strategy, online marketing has a positive impact on the company, because the company has a good product marketing strategy, so that it can achieve company goals or goals easily
\end{abstract}

Keyword: Disruption, Marketing, online marketing

\begin{abstract}
Abstrak
Era disruption adalah suatu era yang akan mengubah bukan hanya cara bisnisnya akan tetapi sampai dengan fundamental bisnisnya, dimulai dari struktur biaya sampai budayanya, bahkan sampai dengan idielogi industrinya.(Renald Kasali, 2017). Pada era disruption perubahan bisnis sangat nampak, cara berbisnis yang dulunya sangat menekankan owning (kepemilikan) menjadi sharing (saling berbagi peran, kolaborasi resources). Salah satu unit dalam perusahaan yang sangat terpengaruh dalam discruption adalah bidang pemasaran. Bidang pemasaran tersebut menjadi ujung tombak perusahaan yang paling cepat terpengaruh. Salah satu bentuk pengaruh discruption dalam pemasaran adalah hadirnya sistem pemasaran Online. Sistim pemasaran tersebut disebut online, karena menggunakan jaringan internet sebagai sarana memasarkan produk barang atau jasa kepada konsumen. Beberapa permasalahan penting yang seringkali dihadapi dalam pemasaran produk secara online adalah, perlunya pemahaman konsep pemasaran secara jelas, kemudian juga pemahaman tentang media yang dapat digunakan, serta strategi pemasaran yang baik. Penelitian dilakukan dengan menggunakan metode diskriptif kualitatif, yaitu menggunakan studi pustaka atau literatur, dengan menggunakan jurnal, buku, majalah, dan web yang relevan dengan penelitian. Kesimpulan dalam penelitian ini adalah Era discruption adalah suatu era yang akan mengubah bukan hanya cara bisnisnya akan tetapi sampai dengan fundamental bisnisnya, permasalahan penting yang seringkali dihadapi dalam pemasaran produk secara online adalah, perlunya pemahaman konsep pemasaran secara jelas, kemudian juga pemahaman tentang media yang dapat digunakan, serta strategi pemasaran yang baik, online marketing memberikan dampak
\end{abstract}


yang positif bagi perusahaan, karena perusahaan memiliki strategi pemasaran produk yang baik, sehingga dapat meraih goal atau tujuan perusahaan dengan mudah.

Kata Kunci: Disruption, Pemasaran, online marketing

\section{PENDAHULUAN}

Pada masa sekarang ini perusahaan telah memasuki era disruption. Banyak perusahaan berupaya melakukan penyesuaian terhadap era tersebut. Karena kemampuan menyesuaikan tersebut mengarahkan perusahaan meraih kemenangan. Era disruption adalah suatu era yang akan mengubah bukan hanya cara bisnisnya akan tetapi sampai dengan fundamental bisnisnya, dimulai dari struktur biaya sampai budayanya, bahkan sampai dengan idielogi industrinya.(Renald Kasali, 2017). Pada era disruption perubahan bisnis sangat nampak, cara berbisnis yang dulunya sangat menekankan owning (kepemilikan) menjadi sharing (saling berbagi peran, kolaborasi resources).

Kalau dahulu semua bisnis perlu dimiliki sendiri, dikuasai sendiri, kalau sekarang justru saling berbagi peran. Dengan demikian kekuatan utama perusahaan pada era disruption adalah, terletak pada seberapa besar kemampuan perusahaan berbagi peran antara stakeholder. Oleh karena itu mainset atau pola pikir yang berkembang adalah bukan sekedar fenomena hari ini, akan tetapi harus mampu berfikir hari esok atau, yang dibawa oleh pembeharu ke masa saat ini. (Renald kasali, 2017). Pola pikir tersebut mengakibatkan setiap pelaku usaha harus memiliki kemampuan untuk belajar, sehingga kita menyadari bahwa setiap saat terjadi perubahan, dan setiap saat diperlukan pembaharuan.

Era disruption sesungguhnya telah terjadi hampir diseluruh industri, baik industri jasa maupun industri manufaktur. Dan terjadi pula di hampir semua profesi, seperti pemerintahan, kedokteran, administrasi, Front office, Kasir, perbankan, pemasaran, dosen, guru, dan profesi lainnya. Hampir semua profesi dituntut untuk banyak belajar terhadap perubahan lingkungan. Karena proses belajar akan mengantarkan kita memahami pembaharuan dalam perubahan. Terdapat lima hal penting dalam era disdruption, yaitu, Pertama, disruption berakibat penghematan banyak biaya melalui proses bisnis yang menjadi lebih simpel. Kedua, ia membuat kualitas apapun yang dihasilkannya lebih baik ketimbang yang sebelumnya. Ketiga, disruption berpotensi menciptakan pasar baru, atau membuat mereka yang selama ini ter-eksklusi menjadi terinklusi. Keempat, produk/jasa hasil disruption ini harus lebih mudah diakses atau dijangkau oleh para penggunanya. Kelima, disruption membuat segala sesuatu kini menjadi serba smart. Lebih pintar, lebih menghemat waktu dan lebih akurat (Renald Kasali, 2017).

Salah satu unit dalam perusahaan yang sangat terpengaruh dalam disruption adalah bidang pemasaran atau marketing. Bidang pemasaran tersebut menjadi ujung tombak perusahaan yang paling cepat terpengaruh. Salah satu bentuk pengaruh disruption dalam pemasaran adalah hadirnya sistem pemasaran online. Sistim pemasaran tersebut disebut online, karena menggunakan jaringan internet sebagai sarana memasarkan produk barang atau jasa kepada konsumen. Dengan kemudahan mengakses internet, maka semua orang mampu melihat, memilih, dan akhirnya memutuskan untuk membeli, hanya dengan melihat berbagai macam jenis produk yang ditampilkan dengan berbagai pilihan harga. Dan dalam hitungan detik, setiap orang sudah bisa memutuskan untuk membeli atau tidak barang yang sudah dilihatnya.

Sistem pemasaran ini menjadi sangat simpel dan sederhana, tetapi mampu memberikan informasi yang lengkap, jelas dan menarik bagi konsumen. Konsumen diberikan ruang belanja yang lebih luas tanpa batas ruang dan waktu, dimanapun kapanpun konsumen dapat melihat dan memilih barang yang akan dibeli. Hal ini sangat berbeda dengan pemasaran konvensional, pemasaran konvensional sangat tergantung pada ruang dan waktu, karena pasar tidak bisa dipindah kemanapun, serta waktu untuk mengakses pun sangat terbatas. 
Beberapa media yang dapat digunakan untuk menjalankan aktivitas pemasaran secara online diantaranya adalah web, blog, yutube,t witer,instagram,facebook, dan beberapa media lainnya. Dengan menggunakan media online tersebut, sebuah produk dapat dipasarkan kepada konsumen dengan cepat, dan tak mengenal batasan waktu. Keunggulan media sosial tersebut menjadi kunci utama keberhasilan pemasaran bagi produk barang maupun jasa. Media sosial adalah media online yang mendukung interaksi sosial. Media sosial menggunakan teknologi berbasis web yang mengubah komunikasi menjadi dialog interaktif. (Ita Suryani, 2014)

Melalui pemasaran online ini sebuah produk diharapkan dapat dijual dengan mudah dan cepat, karena media sosial menjembatani komunikasi pemasaran yang lebih interaktif antara produsen dan konsumen. Komunikasi pemasaran adalah aktivitas pemasaran yang tujuannya untuk menyebarkan informasi, mempengaruhi, membujuk dan mengingatkan pasar sasaran atas perusahaan dan produknya agar bersedia menerima, membeli dan loyal kepada produk yang ditawarkan (Tjiptono, 1997: 29). Diharapkan melalui komunikasi pemasaran yang dibangun menggunakan media online degan baik tersebut akan diperoleh strategi pemasaran yang efektif

Beberapa permasalahan penting yang seringkali dihadapi dalam pemasaran produk secara online adalah, perlunya pemahaman konsep pemasaran secara jelas, kemudian juga pemahaman tentang media yang dapat digunakan, serta strategi pemasaran yang baik. Dengan memahami beberapa pokok permasalahan tersebut, diharapkan pemasaran produk dapat berhasil secara efektif mempengaruhi konsumen untuk membeli.

\section{METODE PENELITIAN}

Penelitian dilakukan dengan menggunakan metode diskriptif kualitatif, yaitu menggunakan studi pustaka atau literatur, dengan menggunakan jurnal, buku, majalah, dan web yang relevan dengan penelitian.

\section{PEMBAHASAN}

Beberapa penelitian terdahulu telah dilakukan analisa tentang efektifas pemasaran online, penelitian tersebut diantaranya
Efektifitas Iklan Pada Jejaring Sosial Sebagai Salahsatu Strategi Pemasaran Bisnis Usaha Kecil Menengah (UKM) Dengan menggunakan metode, disusun oleh Prisma Lisawati, penelitian tersebut dilakukan untuk menguji efektifitas iklan melalui jejaring sosial sebagai salah satu strategi pemasaran produk UKM dengan menggunakan metode EPIC (Emphaty, Persuasion, Impact, Communication). Dari hasil penelitian disampaikan bahwa strategi pemasaran iklan produk melalui jejaring sosial sangat efektif. Selanjutnya peneliti memberikan saran agar para produsen yang aktif memasarkan produknya melalui jejaring sosial perlu memperbaharui atau mengup-date iklan serta informasi produk, sehingga akan terus merangsang ingatan konsumen mengenai produk yang telah dilihat dan terus melakukan promosi penjualan, karena kegiatan promosi mempunyai dampak yang sangat efektif dalam meningkatkan penjualan.

Penelitian yang lain adalah Eksplorasi Faktor-Faktor Online Marketing Yang Memengaruhi Keputusan Konsumen Dalam Belanja Online Pada Naufal Bag Collection, disusun oleh Nia Purwati, Bambang Irawan, Sriyono, penelitian tersebut dilakukan untuk untuk mengeksplorasi faktor-faktor online marketing yang memengaruhi keputusan pembelian dan menganalisis faktor apa yang pengaruhnya paling dominan. Dari hasil penelitian disampaikan bahwa Terdapat lima faktor online marketing yang memengaruhi keputusan konsumen berbelanja secara online pada Naufal Bag Collection Banyuwangi ialah faktor proses transaksi pembelian; faktor potongan harga, faktor kejelasan informasi; faktor keunggulan produk; dan faktor keunggulan pelayanan, namun demikian faktor yang paling dominan mempengaruhi keputusan konsumen untuk membeli melalui belanja online adalah keunggulan produk

Pemanfaatan Media Sosial sebagai Media Pemasaran Produk dan Potensi Indonesia dalam Upaya Mendukung ASEAN Community 2015. (Studi Social Media Marketing Pada Twitter Kemenparekraf RI dan Facebook Disparbud Provinsi Jawa Barat), disusun oleh Ita Suryani, penelitian tersebut dilakukan untuk memberikan uraian secara lengkap dan mendalam mengenai pemanfaatan media 
sosial sebagai media pemasaran dalam upaya mendukung ASEAN Community 2015. Dari hasil penelitian disampaikan bahwa bahwa sejumlah perusahaan yang cerdas, tidak hanya memanfaatkan media sosial sebagai media pemasaran, tetapi sudah menjadi pendukung aktivitas bisnis, mempermudah dan memperkuat fungsi komunikasi kepada publik.

Strategi Pemasaran Melalui Media Sosial dan Minat Beli Mahasiswa, disusun oleh Dewi Kurniawati, Nugraha Arifin, penelitian tersebut dilakukan untuk mengetahui hubungan strategi komunikasi pemasaran Brodo Footwear di Instagram dan minat beli mahasiswa Universitas Sumatera Utara (USU). Hasil analisis penelitian ini menunjukkan bahwa terdapat hubungan yang rendah tetapi pasti antara strategi pemasaran Brodo Footwear dan minat beli mahasiswa di FISIP Universitas Sumatera Utara.

Dari beberapa penelitian terdahulu tersebut kami mencoba melakukan penelitian lanjutan dengan menganalisa efektifitas pemasaran produk melalui online marketing pada era disruption. Penelitian yang akan kami lakukan melengkapi hasil penelitian terdahulu dengan kajian utama yang akan kami lakukan meliputi efektifitas online marketing di era disruption. Penelitian ini kami lakukan dengan metode diskriptif kualitatif, yaitu analisa dengan menggunakan studi pustaka dari beberapa literatur yang relevan.

\section{Konsep Dasar Pemasaran}

Setiap produk yang dihasilkan oleh perusahaan, selanjutnya akan didistribusikan kepada konsumen, proses pendistribusian barang ini melalui proses yang sering disebut dengan istilah pemasaran. Pemasaran menurut Kotler diartikan sebuah proses identifikasi dan pertemuan antara orang dan kebutuhannya, proses tersebut melalui manajemen fungsi dan proses kreatif, komunikasi, dan pengiriman nilai dari produk tersebut kepada konsumen, untuk menghasilkan hubungan yang saling menguntungkan. (Kotler, 2009). Sementara itu Manajemen Marketing diartikan sebagai suatu seni dan ilmu dari memilih target pemasaran dan mengambil, menangkap, dan mengembangkan konsumen melalui kreatifitas dalam berkomunikasi yang dengan konsumen. (Kotler, 2009). Dengan pengertian tersebut dapat dipahami bahwa kunci keberhasilan dalam pemasaran tergantung kepada dua hal yaitu pasar konsumen dan pasar produk tersebut. Pasar konsumen akan menerima banyak produk barang maupun jasa dengan berbagai merek. Kekuatan Merek atau brand tersebut akan sangat tergantung pada kualitas, penampilan (packing), ketersediaan, dan mendukungnya dengan komunikasi yang menarik dan layanan yang handal. Sementara pasar produk harus mampu meberikan edukasi dan informasi secara baik dan profesional, dengan harapan produsen mampu membuat dan menjual produk kepada konsumen dengan memperoleh keuntungan. Dalam proses tersebut terdapat satu hal penting yaitu komunikasi. Komunikasi yang dilakukan antara produsen dengan konsumen dapat dilakukan salah satunya dengan melalui iklan. Dengan iklan tersebut konsumen memahami produk tersebut, dan berupaya untuk membelinya. Terdapat tiga kriteria yang dapat digunakan untuk mengukur efektivitas iklan, yaitu: penjualan, pengingatan, dan persuasi. Efektivitas periklanan yang berkaitan dengan penjualan dapat diketahui melalui riset tentang dampak penjualan, sedangkan efektivitas periklanan yang berkaitan dengan pengingatan dan per-suasi bisa diketahui melalui riset tentang dampak komunikasi. (Premita Lesawati, 2016)

Sementara itu Philip Kotler, mengatakan ada tiga metode utama pra pengujian iklan dalam riset dampak komunikasi, suatu riset yang dilakukan sebelum iklan dimasukkan ke media dan setelah dicetak atau disiarkan. Metode yang pertama adalah metode umpan balik konsumen (consumer feedback method), dilakukan dengan menanyakan reaksi konsumen terhadap iklan yang diusulkan. Metode kedua adalah pengu-jian portofolio, meminta konsumen meli-hat atau mendengarkan suatu portofolio iklan dengan menggunakan waktu sebanyak yang mereka perlukan. Metode ketiga adalah pengujian laboratorium, menggunakan peralatan untuk mengukur reaksi fisiologis detak jantung, tekanan darah, pelebaran bola mata, respons kulit tubuh, keluarnya keringat - terhadap 
iklan. (Premita Lesawati, 2016). Sedangkan Komunikasi pemasaran dapat diartikan "Semua dari marketing mix yang melibatkan komunikasi antar organisasi/perusahaan dan target audiens elemen-elemen pada segala bentuknya yang ditujukan untuk performance marketing".( Prisgunanto, 2006),

Dari konsep dasar pemasaran tersebut, kita dapat memahami bahwa hubungan antara produsen dan konsumen sangat berperan dalam keberhasilan perusahaan memasarkan produknya di pasar.

\section{Pemasaran online}

Meningkatnya jumlah pengguna internet di Indonesia, telah memberikan dampak yang besar bagi perusahaan. Banyak perusahaan melakukan perubahan pada proses bisnisnya, sehingga produk yang merekajual dapat dengan mudah diserap di pasar. Salah satu perubahan yang dilakukan oleh banyak perusahaan adalah sarana atau media pemasaran produk. Perusahaan berupaya mendekatkan pasar produknya dengan cepat kepada konsumen., mereka menggunakan media internet sebagai sarana untuk memasarkan dan menjual produknya.

Online marketing adalah segala upaya yang dilakukan untuk melakukan pemasaran suatu produk atau jasa melalui atau menggunakan media elektronik atau internet. (wikipedia.org). sedangkan jaringan internet adalah Internet jaringan komputer luas dan besar yang mendunia, yaitu menghubungkan pengguna komputer dari suatu tempat ke tempat lain di seluruh dunia. Internet yang merupakan singkatan dari inter dan networking, adalah suatu kumpulan jaringan komputer dan berbagai jenis tipe yang saling berkomunikasi dengan menggunakan suatu standar komunikasi.(Dewi, Nugraha, 2017). Terdapat beberapa jenis marketing online, diantaranya e - marketing, Video marketing, social media marketing. Ketiga jenis pemasaran online tersebut memiliki kesamaan yaitu menggunakan media yang sama yaitu internet. Perbedaan dari ketiga jenis online marketing tersebut adalah, e-marketing menggunakan sarana email sebagai alat untuk menyebarkan informasi produk, video marketing menggunakan sarana video, misalnya youtube, vlog, sedangkan social media marketing menggunakan sosmed sebagai saran memasarkan produk, sosial media tersebut adalah diantaranya facebook, twiter, instagram, wahtsup, Line. Dengan perbedaan tersebut, maka setiap jenis online marketing akan memiliki keunggulan dan kelemahannya.

Dari ketiga jenis online marketing tersebut, sosial media marketing adalah jenis yang sering digunakan oleh perusahaan untuk memasarkan produknya. Media sosial adalah sebuah kelompok aplikasi berbasis internet yang dibangun berdasarkan fondasi ideologis dan teknologi dari web 2.0, yang memungkinkan terjadinya penciptaan dan pertukaran konten yang diciptakan oleh penggunanya (Kaplan Andreas M. \& Haenlein Michael, 2010:59). Media sosial tersebut merupakan bentuk nyata dari online marketing yang menggunakan teknologi terbaru yang berhasil diciptakan oleh manusia. Media sosial memiliki beberapa kelebihan, terutama pada kemampuannya dalam komunikasi dua arah yang interaktif, dan memudahkan penggunanya untuk mengakses berbagai macam informasi.(Ita Suryani, 2014). Pemasaran melalui media sosial (social media marketing) adalah bentuk pemasaran langsung atau tidak langsung untuk membangun kesadaran, dan tindakan untuk sesuatu merek, bisnis, orang, atau badan lain dan dilakukan dengan menggunakan alat-alat dari web sosial, seperti blogging, mikroblogging, jejaring sosial, bookmark sosial, dan konten (Gunelius, 2011:10).

Beberapa media sosial yang dapat digunakan seperti facebook memiliki

\section{Efektifitas Pemasaran Produk Secara online}

Efektifitas adalah suatu ukuran yang menyatakan seberapa jauh target (kuantitas, kualitas dan waktu) yang telah dicapai oleh manajemen, yang mana target tersebut sudah ditentukan terlebih dahulu (Patimeh 2010).

Media pemasaran yang dapat dijalankan oleh perusahaan sekarang ini telah tersedia banyak dan lengkap, media tersebut dapat dipilih oleh perusahaan untuk memasarkan produknya. Dengan banyaknya pilihan tersebut, perusahaan dapat memilih beberapa media yang dapat digunakan, atau bahkan 
menggunakan semua media tersebut. Beberapa media tersebut diantaranya, facebook, instagram, twiter, line, dan lainnya.

Seberapa efektifkah penggunaan media tersebut bagi keberhasilan online marketing perusahaan. Beberapa penelitian diantaranya Prisma Lisawati penelitian tersebut dilakukan untuk menguji efektifitas iklan melalui jejaring sosial sebagai salah satu strategi pemasaran produk UKM dengan menggunakan metode EPIC (Emphaty, Persuasion, Impact, Communication). Dari hasil penelitian disampaikan bahwa strategi pemasaran iklan produk melalui jejaring sosial sangat efektif. Efektivitas iklan dapat diukur dengan menggunakan Model EPIC menurut Durianto, dkk (2003). Alat analisis ini dikembangkan oleh A.C. Nielsen. Model EPIC terdiri dari empat dimensi berikut: Dimensi empati menginformasikan, apakah konsumen menyukai suatu bentuk komunikasi pemasaran dan menggambarkan bagaimana konsumen melihat hu-bungan antara suatu bentuk komunikasi pemasaran dengan pribadinya. Dimensi persuasi menginformasikan apa yang dapat diberikan suatu bentuk komunikasi pemasaran untuk penguatan karakter suatu merek, sehingga pemasar mem-peroleh pemahaman tentang dampak ko-munikasi pemasaran terhadap keinginan konsumen untuk membeli. (Prisma Lisawati, 2017).

Sedangkan penelitian yang lain dilakukan oleh Nia Purwati, Bambang Irawan, Sriyono, dengan judul Eksplorasi Faktor-Faktor Online Marketing Yang Memengaruhi Keputusan Konsumen Dalam Belanja Online Pada Naufal Bag Collection Dari hasil penelitian disampaikan bahwa Terdapat lima faktor online marketing yang memengaruhi keputusan konsumen berbelanja secara online pada Naufal Bag Collection Banyuwangi ialah faktor proses transaksi pembelian; faktor potongan harga, faktor kejelasan informasi; faktor keunggulan produk; dan faktor keunggulan pelayanan, namun demikian faktor yang paling dominan mempengaruhi keputusan konsumen untuk membeli melalui belanja online adalah keunggulan produk, Hasil penelitian tersebut dapat memberikan gambaran bahwa ternyata kekuatan online marketing memberikan dampak yang positif bagi perusahaan, karena perusahaan memiliki strategi pemasaran produk yang baik, sehingga dapat meraih goal atau tujuan perusahaan dengan mudah. Salah satu strategi yang baik adalah bagaimana perusahaan mampu membangun komunikasi tentang nilai - nilai produk kepada konsumen. Perusahaan diharapkan mampu memberikan informasi yang lengkap tentang produk, mampu merangkul konsumen dengan baik, dan mampu melayaninya dengan baik.(Kotler, 2017). Salah satu alat komunikasi yang baik pada era sekarang ini adalah adanya jaringan internet yang dapat dimanfaatkan dengan sepenuhnya oleh perusahaan.

Untuk dapat menjalin komunikasi yang baik dengan konsumen, perusahaan harus dapat melihat profil persaingan yang terjadi. Profil persaingan tersebut, meliputi :1. Siapakah pesaing saat ini dan mendatang, 2. Bagaimanakah kinerja para kompetitor, dan kemampuan apa yang mendorong mereka berprestasi, 3. Bagamanakah setiap kompetitor menempatkan dirinya di pasar, 4. Apa dasar persaingan itu. ( Hermawan Kertajaya, 2000). Dengan mengetahui profile tersebut, maka komunikasi yang dijalankan perusahaan melalui online marketing akan berhasil dengan efektif mempengaruhi konsumen membeli produknya. Disamping itu perusahaan dalam menjalankan komunikasi sebaiknya menyampaikan informasi dengan jelas. Karena faktor informasi yang jelas memiliki pengaruh bagi konsumen untuk membeli produk yang ditawarkan produsen. Hal ini sejalan dengan hasil penelitian yang dilakukan oleh Nia Purwati dan kawan kawan, yang menemukan adanya pengaruh yang kuat antara kejelan informasi dengan keputusan konsumen untuk membeli secara online di naufal bag colection

Beberapa media yang dapat digunakan untuk menjalankan online marketing diantaranya adalah facebook, instagram, dan twiter. Jika kita perhatikan media facebook sebagai sarana online marketing memiliki dominasi yang cukup kuat untuk menjalankan online marketing secara efektif. Menurut data tahun 2014 pengguna aktif bulanan Facebook kini sudah melewati angka 1,19 miliar akun. Dari angka tersebut, 874 juta pengguna di antaranya mengakses Facebook dari perangkat mobile.(Ita Suryani, 2014). Dengan 
semakin banyaknya pengguna facebook, akan memberikan kemudahan bagi perusahaan untuk memasarkan produknya.

Disamping facebook terdapat media lain yaitu instagram yang dapat dimanfaatkan untuk menjalankan online marketing. Data menunjukan bahwa terdapat 1 miliar pengguna aktif Instagram. (Kompas.com). Jumlah ini masih dibawah facebook, akan tetapi kemampuan instagram menggaet kaum milenial patut diperhitungkan, sebab telah banyak anak muda yang sekarang lebih berminat menggunakan instagram dibandingkan facebook. Dengan mengetahui profile pengguna tersebut, maka penggunaan online marketing bagi perusahaan akan berjalan dengan efektif.

Disamping medsos, online marketing juga bisa dibuat menggunakan web site, seperti yang telah dilakukan oleh Traveloka. Traveloka adalah sebuah situs web yang memberikan pelayanan pemesanan kamar hotel secara online. Pada tahun 2017 situs web tersebut telah diunduh sebanyak 15 juta pengunduh. Artinya web site tersebut sangat efektif memberikan pelayanan kepada para konsumen, sehingga konsumen memperoleh kemudahan dari pelayanan tersebut. (beritasatu,com). Dengan jumlah penduh aplikasi yang telah mencapai 15 juta orang, berarti ada potensial buyer yang siap membeli produk yang ditawarkan oleh traveloka.

\section{Online Marketing di era Disruption}

Telah diuraikan di atas, bahwa era disruption adalah era yang menyebabkan terjadinya pengelolaan bisnis secara fundamental, tidak hanya proses bisnisnya akan tetapi sampai dengan idieologi industrinya. Pada masa discuption, perusahaan diharapkan lebih peka membaca perubahan lingkungan dengan pembaharuan yang sesuai. Oleh karena itu inovasi yang diperlukan tidak hanya mengubah bentuk, ukuran, atau desain, tetapi menyeluruh, baik metode, cara kerja, maupun produk yang tidak lagi relevan di zaman milenial.

online marketing sebagai salah satu alat dalam memasarkan produk merupakan bentuk baru dari sebuah pasar. Pasar yang tadinya bersifat konvensional, berubah menjadi bentuk pasar yang bersifat digital, tanpa bentuk, tetapi memiliki jangkauan yang lebih luas tanpa batas. Tentu hal ini merupakan bentuk inovasi baru dalam industri. Namun demikian pada era disruption inovasi baru yang telah terbentuk tersebut tidak cukup hanya berhenti sampai disitu, inovasi online marketing harus terus dikembangkan, seiring perubahan yang semakin cepat terjadi. Perusahaan tidak cukup hanya berinovasi dengan mengubah bentuk, ukuran dan desain saja akan tetapi yang lebih penting adalah kemampuan membaca masa depan. (Ferdian, 2017)

Oleh karena itu di era disruption, online marketing harus dapat memberikan jawaban yang pasti terhadap kebutuhan masa depan. Produk tidak hanya dijual melalui jaringan internet, akan tetapi produknya juga harus mampu menjawab kebutuhan masa depan. Disamping kekuatan produk, tantangan lain adalah penguatan SDM. Hal ini sesuai dengan program Kementrian Tenaga kerja dan Transmigrai RI yang akan memperkuat pembangun SDM di era digital saat ini. Terdapat tiga langkah strategis yang dilakukan Kemnakertrans RI, yaitu penguatan kompetensi, penguatan dan konsisten terhadap nilai dan budaya bangsa, dan penguatan kecintaan terhadap Indonesia. (kompas. com, 2018). Tantangan tersebut dihadapi Indonesia, dikarenakan Indonesia memiliki banyak SDM yang dapat dikembangkan, dan dibekali dengan kemampuan untuk mempelajari teknologi digital, sehingga mereka bisa berinovasi, berkreasi menghasilkan produk digital yang unggul.

Disamping itu era disruption menjadikan sebuah proses produksi dari perusahaan menjadi berbiaya murah, era disruption mampu menciptakan abundanse (berkelimpahan) yang ditandai dengan free economy dan sharing economy. Free economy diantaranya kirim surat gratis lewat e mail, telpon interlokal gratis lewat WA, buku gratis lewat pdfdrive, film dan musik gratis lewat youtube, semua ini semakin lama akan masif terjadi di segala bidang. (Ahmad Faiz Zainuddin, 2018). Dengan munculnya free economy dan sharing economy tersebut, menjadikan tantangan bagi online marketing, agar mampu menumbuhkan inovasi yang baru, yang dapat menarik minat 
konsumen untuk membeli produk yang ditawarkan.

Salah satu contoh bentuk online marketing yang mampu menjawab tantangan disruption adalah pelayanan pemesanan hotel. Setiap orang yang akan menginap di hotel sekarang ini tidak perlu lagi harus datang ke hotel untuk memesan kamar, akan tetapi cukup dari mana saja semua orang sudah bisa memesan kamar yang ditawarkan oleh para perusahaan travel. Bahkan konsumen juga dapat dengan mudah membandingkan harga yang ditawarkan. Sehingga dalam hitungan menit, orang sudah bisa memperoleh kamar yang diinginkan dengan harga yang murah. Banyak yang memperolah keuntungan dari pelayanan ini, dari sisi industri hotel, cara ini dapat menekan biaya reservasi, karena hotel bisa mengurangi tenaga kerja Front Office serta dapat dengan mudah memperoleh tamu yang akan menginap. Sementara dari sisi konsumen, pelayanan ini memberikan kemudahan, kecepatan, dan simpel dalam memesan hotel, dan harga yang diperoleh juga lebih murah. Demikian juga untuk pelayanan tiket pesawat, maupun kereta api.

Selain pelayanan tiket dan reservasi hotel, saat ini juga telah muncul sebuah media online untuk pendidikan yaitu ruangguru, Ruangguru adalah sebuah aplikasi belajar dengan solusi belajar terlengkap untuk segala kesulitan dalam belajar. Konten ini tersedia untuk berbagai jenjang mulai dari SD,SMP,SMA, sesuai dengan kurikulum nasional dan dirancang khusus oleh pengajar terbaik. (ruangguru.com). Media online tersebut memberikan kemudahan bagi para siswa yang ingin mengikuti kursus atau les sesuai dengan jenjang pendidikan yang ditempuh. Dengan biaya yang terjangkau siswa dapat mengikuti les tanpa harus keluar dari rumah, karena proses belajar dilakukan secara online. Dalam era disruption, media belajar online ini, memberikan banyak kemudahan bagi para siswa. Dari dua jenis media online yang telah diuraikan diatas, dapat diketahui bahwa media online dalam era disruption sangat membantu setiap orang untuk memperoleh kemudahan dan dengan biaya yang rendah.

\section{KESIMPULAN}

Era disruption adalah suatu era yang akan mengubah bukan hanya cara bisnisnya akan tetapi sampai dengan fundamental bisnisnya, dimulai dari struktur biaya sampai budayanya, bahkan sampai dengan idielogi industrinya

Beberapa permasalahan penting yang seringkali dihadapi dalam pemasaran produk secara online adalah, perlunya pemahaman konsep pemasaran secara jelas, kemudian juga pemahaman tentang media yang dapat digunakan, serta strategi pemasaran yang baik.

Kekuatan Merek atau brand akan sangat tergantung pada kualitas, penampilan (packing), ketersediaan, dan mendukungnya dengan komunikasi yang menarik dan layanan yang handal. Sementara pasar produk harus mampu meberikan edukasi dan informasi secara baik dan profesional, dengan harapan produsen mampu membuat dan menjual produk kepada konsumen dengan memperoleh keuntungan.

online marketing adalah segala upaya yang dilakukan untuk melakukan pemasaran suatu produk atau jasa melalui atau menggunakan media elektronik atau internet.

Kekuatan online marketing memberikan dampak yang positif bagi perusahaan, karena perusahaan memiliki strategi pemasaran produk yang baik, sehingga dapat meraih goal atau tujuan perusahaan dengan mudah. Salah satu strategi yang baik adalah bagaimana perusahaan mampu membangun komunikasi tentang nilai - nilai produk kepada konsumen.

Di era disruption, online marketing harus dapat memberikan jawaban yang pasti terhadap kebutuhan masa depan. Produk tidak hanya dijual melalui jaringan internet, akan tetapi produknya juga harus mampu menjawab kebutuhan masa depan.

\section{DAFTAR PUSTAKA}

Dewi Kurniawati, Nugraha Arifin, Strategi Pemasaran Melalui Media Sosial dan Minat Beli Mahasiswa, Jurnal Simbolika/Volume 1/Nomor 2/September 2015.

Ita Suryani, Pemanfaatan Media Sosial sebagai

Media Pemasaran Produk dan Potensi Indonesia dalam Upaya Mendukung 
ASEAN Community 2015. (Studi Social Media Marketing Pada Twitter Kemenparekraf RI danFacebook Disparbud Provinsi Jawa Barat), Jurnal komunikasi, ISSN 1907-898X Volume 8, Nomor 2, April 2014

Nia Purwanti, Bambang Irawan1, Sriono, Eksplorasi Faktor-Faktor Online Marketing Yang Memengaruhi Keputusan Konsumen Dalam Belanja Online Pada Naufal Bag Collection, e-Journal Ekonomi Bisnis dan Akutansi, 2017, Volume IV (1) : 84 - 87

Premita Lisawati, Efektifitas Iklan Pada Jejaring Sosial Sebagai Salah Satu Strategi Pemasaran Bisnis Usaha Kecil Menengah (UKM) Dengan Menggunakan Metode, Jurnal Ekonomi Bisnis Volume 21 No.3, Desember 2016

Ifan Harnata Sembiring, Jono M Munandar, Analisis Efektivitas Program Promosi IMOVSES terhadap Tingkat Penggunaan Produk Microsoft Berlisensi pada Sivitas IPB, Jurnal Manajemen dan Organisasi Vol VII, No 1, April 2016

Rizvanda Meyliano Dharma Putra, Inovasi Pelayanan Publik Di Era Disrupsi (Studi Tentang Keberlanjutan Inovasi E-Health Di Kota Surabaya), Jurnal kebijakan dan Manajemen Publik, Volume 6 No. 2 Mei Agustus, 2018, Universitas Airlangga
Kuspuji Catur Bagus Wicaksono, Mengukur Efektifitas Social Media Bagi Perusahaan, Binus Business Review Vol. 4 No. 1 Mei 2013: 551-564, Universitas Binus

Kotler, Keller, Marketing Management, Person Prentice hall, London, 2009

Kaplan, Andreas M, Michael Haenlein. "Users of the world, opportunities of Social Media". Bussines Horizons, 2010.

Patimeh I. Analisa Efektifitas Promosi Wisata pada Obyek Wisata Museum Asi Mbojo. Jurnal Pariwisata. 3(6): 431-443, 2010.

Tjiptono, Fandy. Pemasaran Jasa. Cetakan ke-2. Bayu Media. Malang, 2006

Gurnelius, S,30-minute Sosial Media Marketing. USA: McGraw- Hill Co, 2011

Prisgunanto, Iham. Komunikasi Pemasaran: strategi dan taktik. Ghalia Indonesia. Bogor, 2006

Durianto, Darmadi, \& Liana. Inovasi pasar dengan Iklan yang Efektif. PT. Gramedia Pustaka. Jakarta. 2003

Hermawan Kertajaya, Kotler, Repositioning Asia, Salemba Empat, Jakarta, 2000

Ferdian Anada Majni, Menyusun Strategi Mengatasi Disrupsi, Media Indonesia, 2017

Ahmad Faiz Zainuddin, Menyongsong Era Abundance, liputan 6.com, 2018

Rhenald Kasali, Era Disruption, kompas.com, 2018 